\title{
GROWTH AND SURVIVAL RATE OF VANAME SHRIMP (Litopenaeus vannamei) PL-10 ON DIFFERENT STOCKING DENSITY
}

\author{
Pratiwi $^{1} \cdot$ Muhammad Marzuki $^{1}$ - Bagus Dwi Hari Setyono ${ }^{1}$
}

Ringkasan Litopenaeus vannamei is a commercial shrimp that has high economic value. In recent years, the main commodity contributing to the aquaculture sector in Indonesia is vaname shrimp. Vaname shrimp cultivation aims to meet the increasing market demand. One of the factors that influence the success of vaname shrimp cultivation is the stocking density. This study aims to determine the growth and viability of PL-10 vaname shrimp (Litopenaeus vannamei) fry at different stocking densities. This study used a completely randomized design (CRD). There were 4 treatments, namely $P 1$ with a stocking density of 75 heads $/ 40$ liters, $P 2$ with a stocking density of 150 heads $/ 40$ liters, $P 3$ with a stocking density of 225 heads / 40 liters, and P4 with a stocking density of 300 heads $/ 40$ liters, respectively. 4 repetitions. The research data were analyzed using statistical analysis Univariate One Way Analysis of Variance at $5 \%$ level with a $95 \%$ confidence interval. The results showed that the highest daily growth rate was obtained in treatment $P 1$ with

\footnotetext{
${ }^{1}$ )Program Studi Budidaya Perairan, Universitas Mataram Jl. Pendidikan No. 37 Mataram Indonesia E-mail: pratiwi15031998@gmail.com
}

an average value of $26.836 \pm 0.745 \%$ I day, the highest daily length growth rate was obtained in treatment $P 1$ with an average value of $6.719 \pm 0.103 \%$ / day, the highest absolute weight growth was obtained at treatment P1. P1 treatment with an average value of 0.031 \pm 0.027 gram, absolute length growth was obtained in treatment P1 with an average value of $23.025 \pm 0.667$ $\mathrm{mm}$, the highest survival rate was obtained in treatment $P 2$ with an average value of $96.333 \pm 3.549 \%$, but not different real with treatment P2 (93.333 $\pm 3.443 \%)$ and treatment P4 (92.417 \pm 2.062 ). The conclusion of this study is that stocking density has a significant effect on the growth of vannamei shrimp which are being maintained at the PL-10 stage. The best stocking density in this study was P1 treatment (75 fish / 40 liters).

Keywords vaname shrimp, stocking density, growth, survival rate

\section{PENDAHULUAN}

Litopenaeus vannamei merupakan udang komersial yang mempunyai nilai eko- 
nomis tinggi. Beberapa tahun terakhir ini, komoditas yang berkontribusi utama pada sektor budidaya perikanan di Indonesia adalah udang vaname. Udang vaname resmi diizinkan masuk ke Indonesia melalui KepMenKP No. 41/2001 setelah produksi udang windu menurun sejak tahun 1996 akibat serangan penyakit dan penurunan kualitas lingkungan. Jenis udang ini dirilis secara resmi pada tahun 2001, sejak saat itu peranan vaname sangat nyata menggantikan udang windu (Penaeus monodon) yang terus mengalami penurunan. Keunggulan udang vaname yaitu toleransi terhadap serangan infeksi viral seperti WSSV (White Spot Syndrome Virus), TSV (Taura Syndrome Virus) dan IHHNV (Infectious Hypodermal and Hematopoietic Necrosis Virus).

Budidaya udang vaname bertujuan untuk memenuhi permintan pasar yang semakin meningkat. Permintaan udang secara global naik rata-rata $6-7$ persen per tahun yang kemudian ikut mendorong produksi nasional . Berdasarkan catatan KKP, volume ekspor udang hingga akhir tahun 2018 mencapai 180 ribu ton naik dari 147 ribu ton pada tahun 2017. Menurut Rakhfid et al. (2018) peningkatan produksi udang vaname untuk memenuhi permintaan pasar luar negeri terus dilakukan. Salah satu cara yang ditempuh adalah dengan penerapan teknologi budidaya intensif yang menggunakan perlakuan padat tebar tinggi dan pemberian pakan optimal. Intensifikasi budidaya melalui padat tebar dan laju pemberian pakan yang tinggi dapat menimbulkan masalah kualitas air.

Salah satu faktor penentu keberhasilan budidaya udang adalah pengelolaan kualitas air sebagai media pemelihar- an udang, baik pada kolam atau tambak. Selain kualitas lingkungan budidaya, faktor lain yang memengaruhi keberhasilan budidaya udang vaname adalah kepadatan penebaran. Padat penebaran yang terlalu tinggi akan menyebabkan peningkatan kompetisi udang dalam mendapatkan ruang gerak, pakan maupun oksigen yang berimplikasi pada pertumbuhan yang tidak merata (Rakhfid et al., 2018).

Kepadatan penebaran berperan penting dalam kegiatan budidaya untuk menentukan jumlah benur yang akan siap ditebar dan luas media yang akan digunakan. Perbedaan kepadatan yang ditebar pada setiap media berpengaruh terhadap pertumbuhan dan kelangsungan hidup udang vaname yang dihasilkan (Rakhfid et al., 2017). Kepadatan penebaran benur pada fase nauplii dalam budidaya udang vaname menurut Badan Standarisasi Nasional maksimum 100 ekor per liter.

Pada penelitian yang dilakukan oleh Rakhfid et al. (2017) menunjukkan bahwa kepadatan penebaran berbeda berpengaruh terhadap pertumbuhan udang vaname, pada padat tebar 10 individu/wadah (10 ekor/8 liter $=1,25$ ekor/liter) diperoleh tingkat kelangsungan hidup post larva udang vaname tertinggi yakni sebesar $80,00 \pm 10,00 \%$ dan terendah pada kepadatan penebaran 20 individu/wadah (20 ekor/8 liter $=2,5$ ekor/liter) sebesar $70,00 \pm 10,00 \%$. Hasil ini memberikan gambaran bahwa terjadi penurunan tingkat kelangsungan hidup udang vaname seiring dengan peningkatan padat tebar. Penelitian-penelitian tersebut belum memberikan kesimpulan yang menunjukkan padat tebar yang lebih tinggi untuk kegiatan budidaya udang vaname. 
Kepadatan penebaran udang dalam sebuah wadah pemeliharaan berhubungan dengan pemanfaatan ruang dan kesempatan memperoleh oksigen dan makanan untuk kebutuhan metabolisme udang. Kepadatan penebaran yang tinggi menimbulkan kompetisi antar individu dalam mendapatkan ruang gerak, oksigen dan makanan (Rakhfid et al., 2017). Padat tebar yang tinggi menyebabkan kandungan bahan organik seperti amonia yang berasal dari sisa pakan dan ekskresi dari udang juga makin tinggi. Sisa pakan akan meningkatkan amonia yang bersifat toksik bagi udang. Tujuan penelitian ini untuk mendapatkan informasi tentang kepadatan penebaran yang optimum bagi pertumbuhan dan kelangsungan hidup benur udang vaname.

\section{MATERI DAN METODE}

Penelitian ini dilaksanakan selama 20 hari dari 21 Juli sampai 29 Agustus 2020 di PT. Suri Tani Pemuka Hatchery, Kecamatan Labuhan Badas, Kabupaten Sumbawa, Nusa Tenggara Barat.

Metode penelitian yang digunakan adalah metode eksperimental dengan menggunakan Rancangan Acak Lengkap (RAL) yang terdiri atas 4 perlakuan dengan padat tebar udang vaname yang berbeda. Masing-masing perlakuan dilakukan 4 kali ulangan sehingga diperoleh 16-unit percobaan. Penelitian ini dilaksanakan selama 20 hari. Rancangan penelitian adalah P1 75 ekor/40 liter (1,875 ekor/liter), P2 150 ekor/40 liter (3,75 ekor/liter), P3 225 ekor/40 liter (5,625 ekor/liter), dan P4 300 ekor/40 liter (7,5 ekor/liter).

Parameter yang dianalisis secara statistik adalah laju pertumbuhan spesifik atau specific growth rate (SGR), laju pertumbuhan panjang harian (LPPH), pertumbuhan bobot mutlak (W), pertumbuhan panjang mutlak (L), hubungan panjang dan bobot tubuh, dan tingkat kelangsungan hidup atau survival rate (SR). Perhitungan laju pertumbuhan spesifik dilakukan untuk mengetahui rata-rata pertumbuhan udang vaname dari awal penelitian hingga akhir penelitian, erhitungan laju pertumbuhan panjang harian dilakukan untuk mengetahui rata-rata pertumbuhan udang vaname dari awal penelitian hingga akhir penelitian (Widanarni et al., 2014). Perhitungan pertumbuhan bobot mutlak dilakukan untuk mengetahui pertumbuhan total dari udang vaname dari awal pemeliharaan hingga akhir pemeliharaan dan perhitungan pertumbuhan panjang mutlak dilakukan untuk mengetahui pertumbuhan total dari udang vaname dari awal pemeliharaan hingga akhir pemeliharaan (Batubara et al., 2016) yang persamaannya ditransformasikan dalam bentuk logaritma sebagai bentuk persamaan linear Sumadikarta et al. (2017) dan ditulis dalam bentuk persamaan yang linear sederhana (Damayanti, 2013). Tingkat kelangsungan hidup dihitung untuk mengetahui persentase udang hidup selama pemeliharaan (Nababan et al., 2015).

Data hasil penelitian dianalisis menggunakan Data Analysis pada Software Microsoft Excel dan analisis statistik Univariate One Way Analysis of Variance dengan SPSS pada taraf signifikan $95 \%(\alpha=0,05)$ untuk mengetahui pengaruh dari perlakuan dalam penelitian. Jika data menunjukan pengaruh nyata, maka dilakukan analisis lanjut dengan uji Beda Nyata Terkecil (Duncan's). 


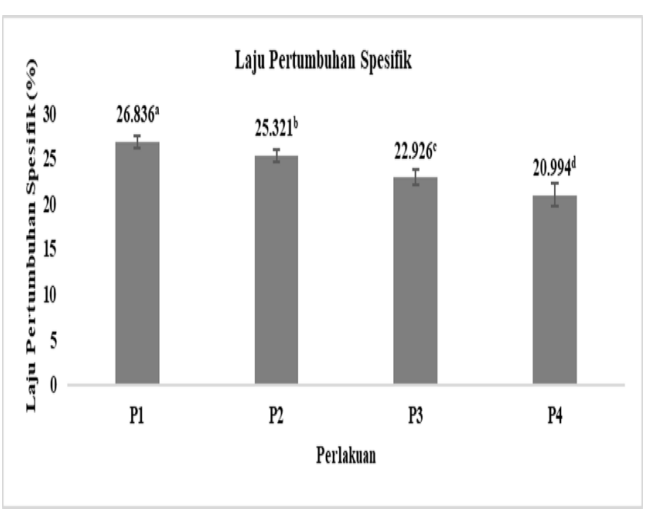

Gambar 1 Laju pertumbuhan spesifik

\section{HASIL DAN PEMBAHASAN}

Berdasarkan hasil analisis statistik uji Duncan's menunjukkan bahwa laju pertumbuhan spesifik pada padat tebar berbeda menunjukkan hasil yang berbeda nyata antar perlakuan. Rata-rata laju pertumbuhan spesifik tertinggi terdapat pada perlakuan P1 26,836\%/hari, diikuti perlakuan P2 25,321\%/hari, selanjutnya P3 22,926\%/hari, dan nilai laju pertumbuhan spesifik terendah adalah pada perlakuan P4 20,994\%/hari dalam 20 hari masa pemeliharaan (Gambar 1).

Laju pertumbuhan spesifik udang vaname dengan rata-rata tertinggi adalah sebesar 26,836\%/hari untuk perlakuan P1 dengan padat tebar 75 ekor/40 liter. Sedangkan laju pertumbuhan spesifik udang vaname dengan rata-rata terendah adalah sebesar 20,994\%/hari untuk perlakuan $\mathrm{P} 4$ dengan padat tebar 300 ekor/40 liter. Menurut Rakhfid et al. (2017) pertumbuhan udang vaname dipengaruhi oleh banyak faktor, salah satunya adalah padat tebar udang yang dipelihara. Keberhasilan dan efektivitas waktu pemeliharaan dalam usaha budidaya diperoleh dengan melihat periode laju pertumbuhan udang tersebut. Salah satu faktor yang menyebabkan tingginya laju pertumbuhan udang adalah baik tidaknya penanganan dalam kegiatan pemeliharaan udang seperti efetivitas waktu pemeliharaan, pakan, dan kontrol lingkungan budidaya (Nababan et al., 2015).

Udang yang dipelihara dengan padat tebar tinggi (300 ekor/40 liter) menunjukkan nilai laju pertumbuhan spesifik yang rendah. Hal ini karena udang tidak dapat tumbuh secara optimal yang disebabkan oleh tingginya persaingan dalam memenuhi kebutuhan makan dan oksigen. Rakhfid et al. (2017) menjelaskan bahwa padat tebar yang tinggi menimbulkan kompetisi antar individu dalam mendapatkan ruang gerak, oksigen dan makanan, sedangkan pada padat tebar rendah (75 ekor/40 liter) menunjukkan nilai laju pertumbuhan spesifik tertinggi. Hal ini karena udang memperoleh ruang gerak, oksigen dan pakan yang cukup untuk mencukupi kebutuhan tubuhnya. Nilai laju pertumbuhan spesifik menjelaskan bahwa udang mampu memanfaatkan nutrien pakan untuk disimpan dalam tubuh dan mengkonversikannya menjadi energi (Harahap and Yusapri, 2015).

Laju pertumbuhan panjang harian tertinggi terdapat pada perlakuan P1 dengan nilai rata-rata $6,719 \% /$ hari, diikuti perlakuan P2 6,437\%/hari, P3 sebesar 5,473\%/hari, dan nilai laju pertumbuhan panjang harian terendah adalah pada perlakuan P4 5,007\%/hari dalam 20 hari masa pemeliharaan (Gambar 2). Berdasarkan hasil analisis statistik uji Duncan's menunjukkan bahwa laju pertumbuhan spesifik pada padat tebar berbeda menunjukkan hasil yang berbeda nyata antar perlakuan.

Laju pertumbuhan panjang harian dengan rata-rata tertinggi adalah sebesar 


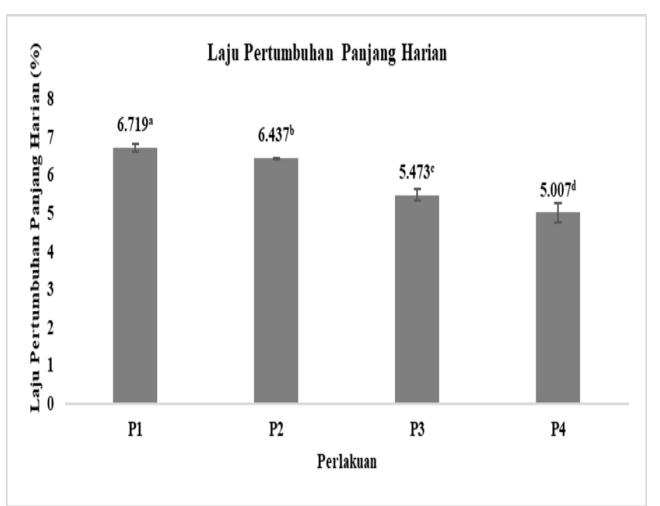

Gambar 2 Laju pertumbuhan panjang harian

6,719\%/hari untuk perlakuan P1 dengan padat tebar 75 ekor/40 liter, sedangkan laju pertumbuhan panjang harian dengan rata-rata terendah adalah sebesar 5,007\%/hari untuk perlakuan P4 dengan padat tebar 300 ekor/40 liter. Hal ini menunjukkan perbedaan padat tebar memengaruhi laju pertumbuhan harian udang vaname. Hal ini karena pada padat tebar tinggi (300 ekor/40 liter) terjadi persaingan dalam memenuhi kebutuhan makanan. Sumadikarta et al. (2017) menjelaskan bahwa pertambahan panjang tubuh udang didukung oleh intensitas udang dalam melakukan molting. Setelah molting nafsu makan udang akan meningkat tinggi guna memuaskan nafsu makannya yang menurun pada saat sebelum molting, sehingga pertumbuhan udang pun juga akan meningkat(Yulihartini et al., 2016). Oleh sebab itu, semakin sering udang molting, semakin cepat pula pertumbuhan udang (Supono, 2019).

Pertumbuhan bobot mutlak tertinggi terdapat pada perlakuan P1 dengan nilai rata-rata 0,231 gram, kemudian diikuti dengan perlakuan $\mathrm{P} 2$ dengan nilai ratarata 0,181 gram, selanjutnya $\mathrm{P} 3$ dengan nilai rata-rata 0,123 gram, dan nilai pertumbuhan bobot mutlak terendah adalah $\mathrm{P} 4$ dengan nilai rata-rata 0,090 gram dalam 20 hari masa pemeliharaan (Gambar 3). Berdasarkan hasil analisis statistik uji Duncan's menunjukkan bahwa bobot mutlak pada padat tebar berbeda menunjukkan hasil yang berbeda nyata antar perlakuan.

Hasil analisis statistik One-Way Anova menunjukkan bahwa perlakuan padat tebar berbeda berpengaruh nyata $(\mathrm{p}<0,05)$ terhadap pertumbuhan bobot mutlak udang yang dipelihara. Udang yang dipelihara dengan padat tebar tinggi (300 ekor/40 liter) menunjukkan nilai pertumbuhan bobot mutlak yang rendah (0,090 gram). Hal ini diduga karena udang tidak dapat tumbuh secara optimal yang disebabkan oleh meningkatnya kompetisi dalam tempat hidup, makanan dan oksigen. Novriadi et al. (2020) menjelaskan bahwa pertumbuhan semakin menurun seiring dengan padat tebar yang semakin meningkat. Mangampa and Suwoyo (2016) menjelaskan bahwa pertambahan bobot badan sangat dipengaruhi oleh konsumsi pakan, karena konsumsi pakan menentukan masukan zat nutrien ke dalam tubuh yang selanjutnya dipakai untuk pertumbuhan dan keperluan lainnya. Nilai pertumbuhan bobot mutlak udang vaname yang rendah, menggambarkan bahwa terjadi kompetisi antar individu yang dalam mendapatkan ruang gerak dan makanan menyebabkan pertumbuhan menjadi terhambat (Rakhfid et al., 2017), sedangkan pada padat tebar rendah (75 ekor/40 liter) menunjukkan pertumbuhan bobot mutlak tertinggi $(0,231$ gram). Padat tebar dikatakan optimal apabila jumlah udang yang ditebar masih dapat ditolerir oleh udang, sehingga pertumbuhan yang dihasilkan tinggi (Rakhfid et al., 2017). 


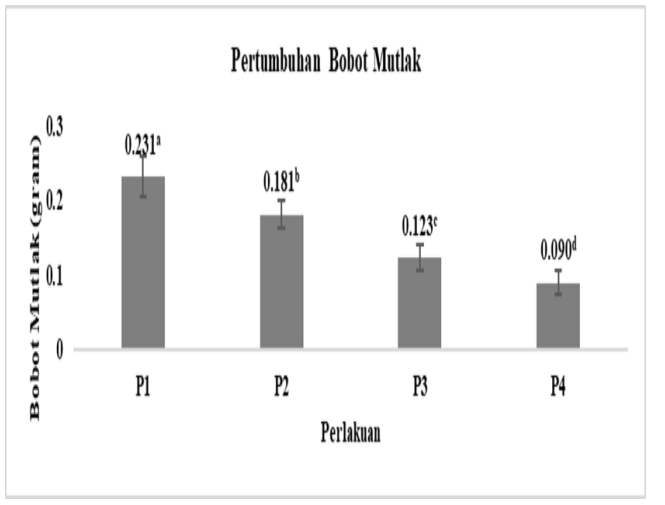

Gambar 3 Pertumbuhan bobot mutlak

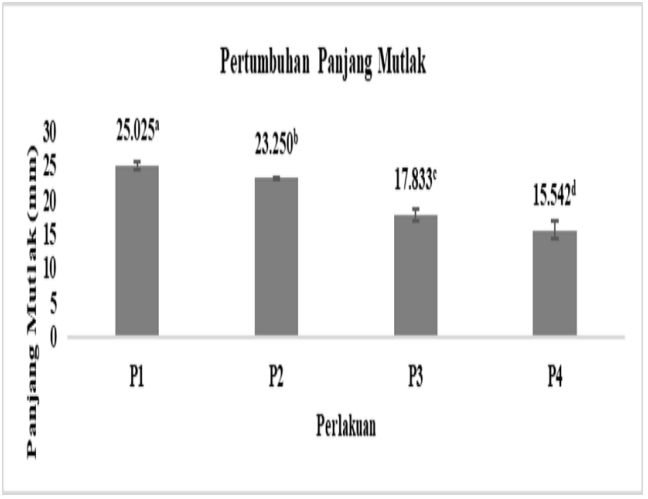

Gambar 4 Pertumbuhan panjang mutlak

Pertumbuhan panjang mutlak tertinggi terdapat pada perlakuan P1 dengan nilai rata-rata $25,025 \mathrm{~mm}$, kemudian diikuti dengan perlakuan P2 dengan nilai rata-rata $23,250 \mathrm{~mm}$, selanjutnya $\mathrm{P} 3$ dengan nilai rata-rata $17,833 \mathrm{~mm}$, dan nilai pertumbuhan panjang mutlak terendah adalah P4 dengan nilai rata-rata 15,542 mm dalam 20 hari masa pemeliharaan (Gambar 4). Berdasarkan hasil analisis statistik uji Duncan's menunjukkan bahwa panjang mutlak pada padat tebar berbeda menunjukkan hasil yang berbeda nyata antar perlakuan.

Berdasarkan hasil pengukuran panjang mutlak udang vaname tertinggi dicapai oleh perlakuan P1 (75 ekor/40 liter) dengan nilai rata-rata sebesar 25,025 $\mathrm{mm}$, sedangkan nilai rata-rata terendah adalah pada perlakuan P4 (300 ekor/40 liter) sebesar 15,542 mm. Perbedaan panjang mutlak udang pada perlakuan P1 (75 ekor/40 liter) dan pada perlakuan P4 (300 ekor/40 liter) diduga dipengaruhi oleh kemampuan udang dalam memperoleh makanan karena adanya perbedaan padat tebar. Pertumbuhan udang dipengaruhi oleh umur, kepadatan, dan kemampuan memanfaatkan makanan (Mangampa and Suwoyo, 2016). Perlakuan padat tebar tinggi (300 ekor/40 liter) udang cenderung mengalami persaingan dalam mendapatkan makanan. Kepadatan tinggi akan meningkatkan kompetisi dalam tempat hidup, makanan, dan oksigen. Sehingga untuk kolam intensif harus diimbangi dengan teknologi yang tepat (Arsad et al., 2017). Kondisi tersebut menyebabkan pertumbuhan udang akan menurun. Lestari et al. (2018) tingkat konsumsi pakan akan memengaruhi pertumbuhan individu maupun biomassa pada akhir pemeliharaan, yang berkaitan dengan optimalisasi pertumbuhan udang.

Berdasarkan hasil analisis hubungan panjang dan bobot tubuh udang vaname, model perhitungan hubungan panjang dan bobot tubuh udang vaname yang dipelihara selama 20 hari adalah y = $-0,254+0,014 x$ dengan nilai R2 sebesar 0,972 (Gambar 5). Berdasarkan hasil uji Correlation dengan nilai sebesar 0,985 menunjukkan bahwa panjang dan bobot tubuh udang vaname memiliki hubungan yang erat. Panjang tubuh udang vaname sangat memengaruhi bobot tubuhnya. Sumadikarta et al. (2017) nilai korelasi yang berkisar antara $0,7-1,0$ berarti memiliki nilai korelasi yang tinggi, sedangkan nilai 0,0 - 0,2 memiliki nilai korelasi yang rendah (tidak berkorelasi). Hasil analisis regresi dan grafik hubungan panjang dan 


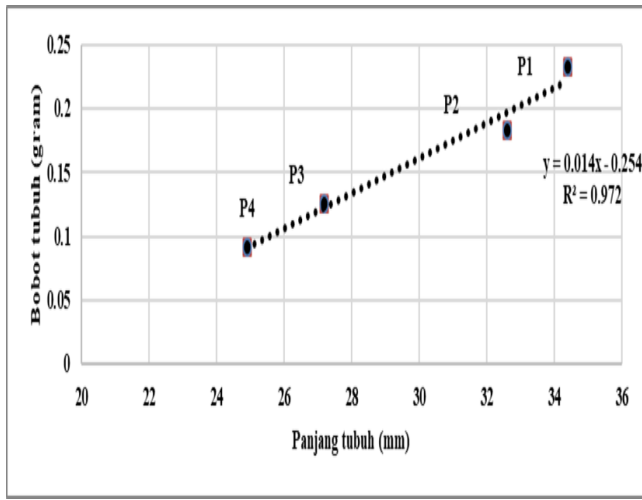

Gambar 5 Hubungan panjang dan bobot tubuh udang

bobot tubuh udang memiliki persamaan regresi $\mathrm{y}=-0,254+0,014 \mathrm{x}$ dengan koefisien determinasi R2=0,972. Artinya $97,2 \%$ pertambahan bobot tubuh udang vaname terjadi karena pertambahan panjang tubuh udang, sedangkan $2,8 \%$ pertambahan bobot tubuh udang vaname disebabkan oleh faktor lain seperti faktor lingkungan dan umur. Pertumbuhan udang dipengaruhi oleh umur, kepadatan, dan kemampuan memanfaatkan makanan (Mangampa and Suwoyo, 2016).

Berdasarkan persamaan regresi (Gambar 5) dapat dilihat nilai b sebesar 0,014 $(\mathrm{b}<3)$ menunjukkan pola pertumbuhan alometrik negatif, artinya pertambahan panjang tubuh udang vaname lebih cepat dari pertambahan bobot tubuhnya (Sumadikarta et al., 2017).

Berdasarkan hasil analisis kepadatan penebaran tidak terdapat perbedaan yang nyata pada kelangsungan hidup udang vaname. Hal ini dikarenakan nilai signifikansi $>\alpha(0,05)$. Tingkat kelangsungan hidup udang vaname tertinggi terdapat pada perlakuan P2 dengan nilai rata-rata 96,333\%, kemudian diikuti dengan perlakuan $\mathrm{P} 1$ dengan nilai ratarata $96,333 \%$, selanjutnya $\mathrm{P} 4$ dengan nilai rata-rata $92,417 \%$, dan nilai kelangsungan hidup terendah adalah P3 dengan nilai rata-rata $88,444 \%$ dalam 20 hari masa pemeliharaan (Gambar 6).

Kelangsungan hidup tertinggi ditunjukkan oleh perlakuan P2 (150 ekor/40 liter) sebesar $96,333 \%$. Akan tetapi berdasarkan dari hasil uji Duncan's, nilai kelangsungan hidup pada perlakuan P2 tidak berbeda nyata dengan perlakuan P1 (75 ekor/40 liter) sebesar 93,333\% dan P4 (300 ekor/40 liter) sebesar 92,417\%. sedangkan kelangsungan hidup terendah terdapat pada perlakuan P3 (225 ekor/40 liter) sebesar $88,444 \%$ dan berbeda nyata dengan perlakuan P2 (150 ekor/40 liter) sebesar 96,333\%, namun tidak berbeda nyata dengan perlakuan P1 (75 ekor/40 liter) sebesar 93,333\% dan P4 (300 ekor/40 liter) sebesar 92,417\%.

Kelangsungan hidup udang vaname dipengaruhi oleh kualitas air dan pakan. Faktor yang paling memengaruhi tingkat kelulushidupan larva udang vaname yaitu kualitas air pada media pemeliharaan dan kualitas pakan (Lestari et al., 2018). Berdasarkan pengamatan diketahui bahwa tingkat kelangsungan hidup dari semua perlakuan menunjukkan nilai yang cukup tinggi, hal ini diduga karena kualitas air selama pemeliharaan dalam kondisi optimal dan dapat ditolerir oleh udang vaname. Faktor yang memengaruhi tinggi rendahnya kelangsungan hidup adalah faktor abiotik dan biotik. Faktor abiotik adalah parameter fisika dan kimia air. Proses fisiologis udang akan berjalan dengan baik apabila lingkungan hidupnya berada dalam kisaran yang dapat ditoleransi, sehingga dapat mempertahankan hidupnya (Marlina and Panjaitan, 2020).

Selama penelitian kualitas air yang diukur adalah suhu, $\mathrm{pH}$, oksigen terlarut, salinitas dan kadar amonia $\left(\mathrm{NH}_{3}\right)$. Ber- 


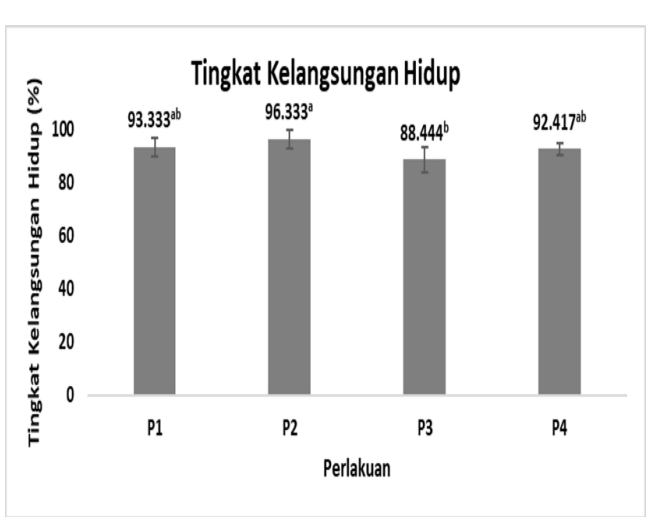

Gambar 6 Tingkat kelangsungan hidup

dasarkan hasil pengukuran kualitas air selama 20 hari masa pemeliharaan (Tabel 2) diketahui bahwa kualitas air pada semua perlakuan menunjukkan nilai yang tidak berbeda signifikan. Hasil penelitian menunjukkan bahwa kisaran suhu air media pemeliharaan pada pagi hari adalah $22,2-26,9^{\circ} \mathrm{C}$ sedangkan pada sore hari sebesar 24,3 $28,3^{\circ} \mathrm{C}$. Hasniar et al. (2012) menyatakan bahwa setiap spesies udang mempunyai kisaran suhu optimal. Kisaran suhu yang optimum untuk pertumbuhan udang vaname yaitu $28-31^{\circ} \mathrm{C}$ (Arsad et al., 2017) dan tumbuh dengan baik pada suhu $23-30^{\circ} \mathrm{C}$ (Suwoyo et al., 2018). Kualitas air yang diukur selama penelitian dapat dilihat pada Tabel 7. Suhu diukur setiap pagi hari (08.00) dan sore hari (16.00). DO, pH, salinitas dan amonia diukur pada awal pemeliharaan, hari ke-10 pemeliharaan dan akhir pemeliharaan.

Hasil penelitian menunjukkan bahwa $\mathrm{pH}$ air media pemeliharaan udang vaname dari semua perlakuan masih dalam batas toleransi yang cocok untuk pemeliharaan udang vaname, yaitu dalam kisaran 7,8 - 8,7 (Tabel 2). Lestari et al. (2018) derajat keasaman $(\mathrm{pH})$ yang baik untuk budidaya udang adalah 7,4 - 8,9. Sedangkan menurut Has- niar et al. (2012) derajat keasaman air laut yang normal adalah 7,0-8,5.

Hasil penelitian menunjukkan oksigen terlarut air pemeliharaan dari semua perlakuan masih dalam batas toleransi yang sesuai untuk kehidupan udang vaname, yaitu dalam kisaran $6,4-11,25 \mathrm{mg} / \mathrm{l}$ (Tabel 2). Lestari et al. (2018) menjelaskan bahwa kondisi oksigen terlarut yang baik untuk budidaya udang adalah minimal $3 \mathrm{mg} / \mathrm{l}$. Apabila kandungan oksigen terlarut pada media budidaya kurang dari batas toleransi maka dapat menurunkan pertumbuhan dan sintasan udang vaname. Oksigen terlarut di bawah $3 \mathrm{mg} / \mathrm{l}$ dapat menyebabkan udang stress dan mengalami kematian (Arsad et al., 2017).

Hasil penelitian menunjukkan salinitas air pemeliharaan udang vaname dari semua perlakuan dalam kisaran yang baik untuk hidup udang vaname yaitu sebesar $29-35$ ppt (Tabel 2) salinitas yang ideal untuk pertumbuhan udang antara $10-35$ ppt.

Hasil penelitian menujukkan bahwa kadar amonia pada air pemeliharaan dari semua perlakuan berkisar antara 0,00 $0,25 \mathrm{mg} / \mathrm{l}$, nilai ini masih dalam batas normal yang dapat ditolerir untuk pertumbuhan udang vaname. Sesuai dengan pernyataan Mangampa and Suwoyo (2016) bahwa konsentrasi $\mathrm{NH}_{3}$ lebih dari 1,0 $\mathrm{mg} / \mathrm{l}$ dapat menyebabkan kematian udang.

\section{SIMPULAN}

Berdasarkan hasil penelitian, dapat disimpulkan bahwa kepadatan penebaran memiliki pengaruh nyata terhadap pertumbuhan udang vaname. Namun tidak berpengaruh nyata terhadap tingkat kelangsungan hidup udang vaname 
Tabel 1 Hasil Pengukuran Kualitas Air

\begin{tabular}{cccc}
\hline Parameter & Perlakuan & Nilai Kisaran & Nilai Optimum \\
\hline \multirow{3}{*}{ Suhu $\left({ }^{\circ} \mathrm{C}\right)$} & 1 & $22,2-28,1$ & $23-30$ \\
& 2 & $22,4-28,3$ & \\
& 3 & $22,6-28,2$ & $7,4-8,9$ \\
$\mathrm{pH}$ & 4 & $22,2-28,2$ & \\
& 1 & $7,8-8,6$ & $>3 \mathrm{mg} / 1$ \\
DO $(\mathrm{mg} / \mathrm{l})$ & 2 & $8,4-8,6$ & \\
& 3 & $8,5-8,7$ & \\
& 4 & $7,8-8,6$ & $15-35$ \\
Salinitas (ppt) & 1 & $7,65-8,11$ & \\
& 2 & $6,4-8,42$ & \\
& 3 & $6,77-9,05$ & \\
& 4 & $29-32-35$ & \\
Amonia (mg/l) & 1 & $32-34$ & \\
& 2 & $0,00-0,25$ & \\
\hline
\end{tabular}

sampai kepadatan 300 ekor/40 liter. Padat tebar terbaik dalam penelitian ini adalah 75 ekor/40L dengan laju pertumbuhan spesifik 26,836\%/hari, laju pertumbuhan panjang harian 6,719\%/hari, bobot mutlak 0,231 gram, panjang mutlak 25,025 mm, dan tingkat kelangsungan hidup sebesar 93,333\%

\section{Pustaka}

Arsad, S., Afandy, A., Purwadhi, A. P., Saputra, D. K., Buwono, N. R., et al. (2017). Studi kegiatan budidaya pembesaran udang vaname (litopenaeus vannamei) dengan penerapan sistem pemeliharaan berbeda [study of vaname shrimp culture (litopenaeus vannamei) in different rearing system]. Jurnal Ilmiah Perikanan dan Kelautan, 9(1):1-14.

Batubara, J. P. et al. (2016). Laju pertumbuhan dan kelangsungan hidup udang galah (macrobranchium rosenbergii de man) skala laboratorium. Jurnal Perikanan, 1(1).
Damayanti (2013). Hubungan panjang bobot dan faktor kondisi ikan layang (decapterus macrosoma bleeker, 1851) tertangkap di perairan selat makasar, sulawesi selatan (skripsi). Master's thesis, Universitas Hasanuddin.

Harahap, S. R. and Yusapri, A. (2015). Pengaruh pemberian pakan berbeda terhadap pertumbuhan ikan betutu (oxyeleotris marmorata. blkr.) dalam jaring hapa. Berkala Perikanan Terubuk, 43(1):1-11.

Hasniar, H., Firman, F., and Yunarti, Y. (2012). Efektifitas penggunaan probiotik dan antibiotik terhadap kualitas air dalam meningkatkan sintasan post larva. Jurnal Galung Tropika, 2(1).

Lestari, I., Yuniarti, T., et al. (2018). Penggunaan copepoda, oithona sp. sebagai subtitusi artemia sp., terhadap pertumbuhan dan kelulushidupan larva udang vaname (litopenaeus vannamei). Journal of Aquaculture Management and Technology, 7(1):90-98. 
Mangampa, M. and Suwoyo, H. S. (2016). Budidaya udang vaname (litopenaeus vannamei) teknologi intensif menggunakan benih tokolan. Jurnal Riset Akuakultur, 5(3):351361.

Marlina, E. and Panjaitan, I. (2020). Optimal stocking density of vannamei shrimp lytopenaeus vannamei at low salinity using spherical tarpaulin pond. In IOP Conference Series: Earth and Environmental Science, volume 537, page 012041. IOP Publishing.

Nababan, E., Iskandar, P., and Rusliadi (2015). Pemeliharaan udang vaname (litopenaeus vannamei) dengan persentase pemberian pakan yang berbeda. Jurnal Perikanan dan Ilmu Kelautan.

Novriadi, R., Alfitri, K. N., Supriyanto, S., Kurniawan, R., Deendarlianto, D., Rustadi, R., Wiratni, W., and Rahardjo, S. (2020). Pengaruh padat tebar dan penggunaan injektor venturi terhadap laju pertumbuhan udang (litopenaeus vannamei) dalam bak beton. Jurnal Perikanan Universitas Gadjah Mada, 22(2):141-147.

Rakhfid, A., Baya, N., Bakri, M., and Fendi, F. (2017). Growth and survival rate of white shrimp (litopenaeus vannamei) at different density. Akuatikisle: Jurnal Akuakultur, Pesisir dan Pulau-Pulau Kecil, 1(2):1-6.

Rakhfid, A., Halida, W. O., Rochmady, R., and Fendi, F. (2018). Probiotic aplication for growth and survival rate of vaname shrimp litopenaeus vannamei with different density. Akuatikisle: Jurnal Akuakultur, Pesisir dan Pulau-Pulau Kecil, 2(2):4148.

Sumadikarta, A., Srie, R., and Rahman (2017). Korelasi antara panjang dan berat udang vaname (litopenaeus vannamei) yang dipelihara secara intensif dengan kepadatan berbeda. Jurnal Perikanan dan Ilmu Kelautan, 1(1).

Supono, S. (2019). Teknologi Produksi Udang. Plantaxia.

Suwoyo, H. S., Fahrur, M., Syah, R., et al. (2018). Pengaruh jumlah titik aerasi pada budidaya udang vaname, litopenaeus vannamei. Jurnal Ilmu dan Teknologi Kelautan Tropis, 10(3):727-738.

Widanarni, Noermala, J., and Sukenda (2014). Pemberian prebiotik, probiotik, dan sinbiotik untuk pengendalian ko-infeksi vibrio harveyi dan infectious myonecrosis virus pada udang vaname litopenaeus vannamei. Jurnal Akuakultur Indonesia, 13(1):11-20.

Yulihartini, W., Rusliadi, R., and Alawi, H. (2016). Effect of adding calcium hydroxide ca (oh) 2 on molting, growth and survival rate vannamei shrimp (litopenaeus vannamei). Jurnal Perikanan dan Ilmu Kelautan Riau.

Kontribusi: Pratiwi : Mengambil data Lapangan, Analisis Data dan Menulis Hasil Penelitian; Marzuki, M: Pembahasan; Bagus Dwi Hari Setyono, B D H: Pembahasan dan Editing. 